\title{
ANALYTIC NETWORK PROCESS (ANP) PADA BALANCED SCORECARD (BSC) DENGAN PENDEKATAN FUZZY
}

\author{
Oni Soesanto ${ }^{1}$, M. Mahfuzh Shiddiq ${ }^{2}$, Oktarini $^{3}$ \\ ${ }^{123}$ Program Studi Matematika FMIPA ULM \\ Jl. A. Yani Km 36 Banjarbaru, Kalimantan selatan
}

\begin{abstract}
ABSTRAK
Himpunan fuzzy merupakan perkembangan dari himpunan klasik. Himpunan fuzzy digunakan sebagai dasar dalam logika fuzzy. Logika fuzzy banyak diterapkan pada penelitian teknik pengambilan keputusan. Teknik pengambilan keputusan yang menerapkan logika fuzzy juga dapat digunakan dalam Balanced ScoreCard (BSC). Salah satu metode teknik pengambilan keputusan adalah Fuzzy Analytic Hierarchy Process (FAHP). FAHP telah diterapkan dalam BSC, namun tidak mencerminkan kondisi BSC sehingga diperlukan metode lain yang memperhatikan keterkaitan antar aspek, yaitu Fuzzy Analytic Network Process (FANP). FANP mampu memperbaiki kelemahan FAHP berupa kemampuan mengakomodasi keterkaitan antar kriteria atau alternatif. Paper ini membahas konsep pendekatan Fuzzy pada metode ANP menggunakan extent analysis method untuk mengukur kinerja perusahaan berdasarkan indikator dalam perspektif BSC.
\end{abstract}

Kata Kunci: Balanced Scorecard (BSC), Metode extent analysis, Fuzzy Analytic Network Process (FANP), Triangular Fuzzy Number (TFN)

\section{PENDAHULUAN}

Logika fuzzy banyak diterapkan dalam teknik pengambilan keputusan yang digunakan dalam berbagai bidang. Kahraman et al. (2003) menggunakan logika fuzzy dalam sistem pengambilan keputusan dalam pemilihan lokasi. Dalam Abdurrahman (2011), metode tsukamoto (Logika Fuzzy) digunakan pada sistem pendukung keputusan untuk menentukan jumlah produksi barang berdasarkan data persediaan dan jumlah permintaan.

Teknik-teknik pengambilan keputusan yang menerapkan logika fuzzy juga dapat digunakan dalam Balanced Scorecard (BSC). Kaplan dan Norton (1996) menyatakan bahwa BSC merupakan salah satu metode yang digunakan dalam pengukuran kinerja perusahaan berdasarkan empat perspektif, yaitu financial (Keuangan), customer (Pelanggan), internal business process (Proses Internal Bisnis) dan learning and development (Proses Pembelajaran dan Perkembangan).

Lee et al. (2008), menggunakan salah satu teknik pengambilan keputusan, yaitu Fuzzy-Analytic Hierarchy Process (FAHP) yang diintegrasikan ke dalam BSC. Namun, menurut Rosid (2009) FAHP tidak mencerminkan kondisi dari konsep dasar Balanced Scorecard (BSC) yaitu adanya saling keterkaitan antar aspek kinerja. Oleh karena itu, diperlukan metode lain yang memperhatikan 
keterkaitan antar aspek kinerja, yaitu metode Fuzzy Analytic Network Process (FANP) yang merupakan perkembangan dari Fuzzy Analytic Hierarchy Process (FAHP). Dalam paper ini dibahas penggunaan FANP pada BSC untuk penentuan kinerja dari suatu perusahaan dengan sintesis fuzzy menggunakan Extent Analysis Method.

\section{METODOLOGI PENELITIAN}

\subsection{Himpunan Fuzzy}

Teori himpunan fuzzy diperkenalkan pertama kali oleh Zadeh (1965). Teori ini menyatakan bahwa derajat keanggotaan dari suatu elemen himpunan bukanlah hanya terdiri dari 0 dan 1 , namun dalam rentang $[0,1]$. Logika yang berdasarkan pada teori himpunan fuzzy disebut dengan logika fuzzy.

\section{Definisi 1 [Chang, 1996]}

Didefinisikan sebuah bilangan fuzzy $M$ di $\mathbb{R}$ menjadi bilangan fuzzy segitiga, jika fungsi keanggotaannya $\mu_{M}(x): \mathbb{R} \rightarrow[0,1]$ adalah sama dengan

$$
\mu_{M}(x)=\left\{\begin{array}{l}
\frac{x-l}{m-l}, x \in[l, m], \\
\frac{x-u}{m-u}, x \in[m, u], \\
0, \text { untuk yang lain }
\end{array}\right.
$$

dimana $l \leq m \leq u$, dengan $l, m$, u secara berurutan adalah nilai bawah,nilai tengah dan nilai atas dari M. Triangular Fuzzy Number dapat dilambangkan dengan (l, $m$, u). Support dari $M$ adalah himpunan tegas dengan $\{x \in \mathbb{R} \mid l<x<u\}$. Ketika $l=$ $m=u$,maka nilai tersebut bukan bilangan fuzzy segitiga yang akan membentuk kurva segitiga.

\subsection{Extent Analysis Method}

Berikut adalah langkah-langkah yang terdapat dalam extent analysis method atau metode Chang:

a. Menentukan nilai sintetis fuzzy

Definisi 2 [Chang, 1996]

Diberikan $M_{g i}^{1}, M_{g i}^{2}, \ldots, M_{g i}^{m}$ menjadi nilai-nilai analisis tingkat objek untuk $m$ tujuan. Maka nilai sintesis perluasan fuzzy sehubungan dengan objek ke-i, didefinisikan sebagai:

$$
S_{i}=\sum_{j=1}^{m} M_{g i}^{j} \odot\left[\sum_{i=1}^{n} \sum_{j=1}^{m} M_{g i}^{j}\right]^{-1}
$$

dimana:

$$
\begin{aligned}
& \sum_{j=1}^{m} M_{g i}^{j}=\left(\sum_{j=1}^{m} l_{i}, \sum_{j=1}^{m} m_{i}, \sum_{j=1}^{m} u_{i}\right) \\
& {\left[\sum_{i=1}^{n} \sum_{j=1}^{m} M_{g i}^{j}\right]^{-1}=\left(\frac{1}{\sum_{j=1}^{m} u_{i}}, \frac{1}{\sum_{j=1}^{m} m_{i}}, \frac{1}{\sum_{j=1}^{m} l_{i}}\right)}
\end{aligned}
$$

b. Menentukan derajat kemungkinan (degree of possibility) dari $M_{2} \geq M_{1}$

Definisi 3 [Chang, 1996]

Derajat kemungkinan (degree of possibility) dari $M_{1} \geq M_{2}$ didefinisikan sebagai 


$$
\begin{aligned}
V\left(M_{2} \geq M_{1}\right) & \left.=\operatorname{hgt}\left(M_{1} \cap M_{2}\right) M_{2}\right)=\sup _{x \geq y}\left[\min \left(\mu_{M_{1}}(x), \mu_{M_{2}}(y)\right)\right] \\
& =\left\{\begin{array}{cc}
1 & \text {,jika } m_{2} \geq m_{1} \\
0 & \text {,jika } l_{1} \geq u_{2} \\
\frac{l_{1}-u_{2}}{\left(m_{2}-u_{2}\right)-\left(m_{1}-l_{1}\right)}, \text {, untuk nilai yang lain }
\end{array}\right.
\end{aligned}
$$

untuk membandingkan $M_{1}$ dan $M_{2}$, diperlukan kedua nilai dari $V\left(M_{1} \geq M_{2}\right)$ dan $V\left(M_{2} \geq M_{1}\right)$.

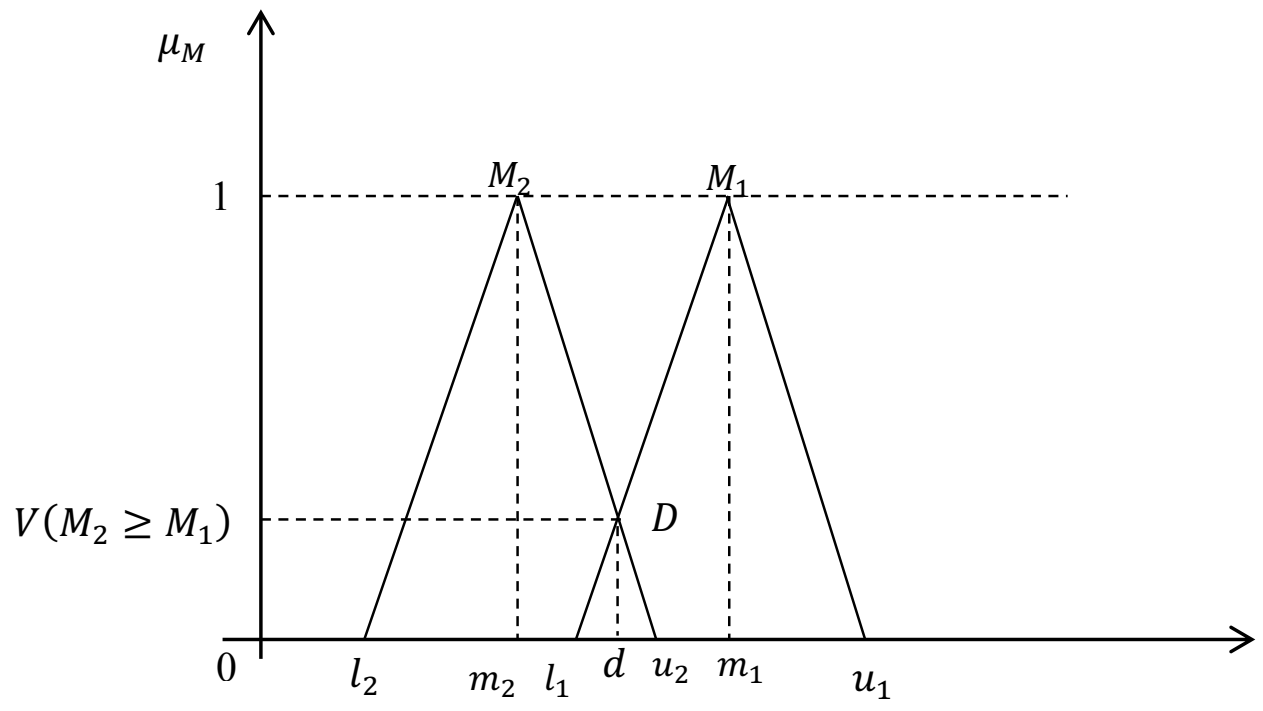

Gambar 1. Irisan $\mathrm{M}_{1}$ dan $\mathrm{M}_{2}$

c. Menentukan derajat kemungkinan (degree possibility) untuk bilangan konveks fuzzy

\section{Definisi 4 [Chang, 1996]}

Derajat kemungkinan (degree possibility) untuk bilangan konveks fuzzy lebih besar dari bilangan konveks fuzzy $M_{i}(i=1,2, \ldots, k)$ dapat didefinisikan oleh :

$$
\begin{aligned}
& V\left(M \geq M_{1}, M_{2}, \ldots, M_{k}\right) \\
& =V\left[\left(M \geq M_{1}\right) \wedge V\left(M \geq M_{2}\right) \wedge \ldots \wedge V\left(M \geq M_{k}\right)\right] \\
& \quad=\min V\left(M \geq M_{i}\right), \quad i=1,2, \ldots, k
\end{aligned}
$$

Diasumsikan bahwa

$$
d^{\prime}\left(A_{i}\right)=\min V\left(S_{i} \geq S_{k}\right)
$$

untuk $k=1,2, \ldots, n ; k \neq i$ maka vektor bobot diberikan oleh

$$
W^{\prime}=\left(d^{\prime}\left(A_{1}\right), d^{\prime}\left(A_{2}\right), \ldots, d^{\prime}\left(A_{n}\right)\right)^{T}
$$

dimana $A_{i}(i=1,2, \ldots, n)$ adalah kriteria/subkriteria.

Melalui normalisasi, didapatkan vektor bobot normal

dimana $W$ adalah bilangan tak fuzzy.

$$
W=\left(d^{\prime}\left(A_{1}\right), d^{\prime}\left(A_{2}\right), \ldots, d^{\prime}\left(A_{n}\right)\right)^{T}
$$


Adapun tabel skala Triangular Fuzzy untuk membuat matriks perbandingan kepentingan berpasangan pada Extent Analysis Method (Chang 1996) adalah sebagai berikut:

Tabel 1. Skala Triangular Fuzzy untuk matriks perbandingan pada Extent Analysis Method

\begin{tabular}{lcc}
\hline \multicolumn{1}{c}{ Skala Linguistik } & $\begin{array}{c}\text { Skala Triangular } \\
\text { Fuzzy }\end{array}$ & $\begin{array}{c}\text { Skala Triangular } \\
\text { Fuzzy Resiprokal }\end{array}$ \\
\hline Tetap & $(1,1,1)$ & $(1,1,1)$ \\
Sama Pentingnya & $(1 / 2,1,3 / 2)$ & $(2 / 3,1,2)$ \\
Sedikit Lebih Penting & $(1,3 / 2,2)$ & $(1 / 2,2 / 3,1)$ \\
Sangat Lebih Penting & $(3 / 2,2,5 / 2)$ & $(2 / 5,1 / 2,2 / 3)$ \\
Sangat Kuat Lebih Penting & $(2,5 / 2,3)$ & $(1 / 3,2 / 5,1 / 2)$ \\
Mutlak Lebih Penting & $(5 / 2,3,7 / 2)$ & $(2 / 7,1 / 3,2 / 5)$ \\
\hline
\end{tabular}

(Sumber: Yüksel I. \& M. Dağdeviren, 2010)

\subsection{Fuzzy Analytic Network Process (FANP)}

Metode Analytic Network Process (ANP) merupakan pengembangan dari metode Analytical Hierarchy Process (AHP). Analytical Hierarchy Process (AHP) adalah salah satu metode yang digunakan untuk menyelesaikan pengambilan keputusan dengan multikriteria atau Multi Criteria Decision Making (MCDM). AHP diperkenalkan oleh Prof. Thomas Lorie Saaty pada periode 1971-1975 ketika di Wharton Business School. Penerapan metode AHP adalah untuk membuat urutan alternatif keputusan dan memilih yang terbaik pada saat pengambil keputusan memiliki beberapa tujuan atau kriteria untuk mengambil keputusan tertentu (Tominanto, 2012). AHP mempunyai kelemahan yaitu, tidak memperhatikan keterkaitan antar kriteria atau alternatif. Berikut struktur perbedaan antara AHP dan ANP .

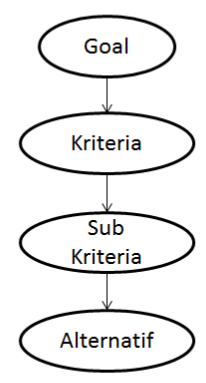

(a)

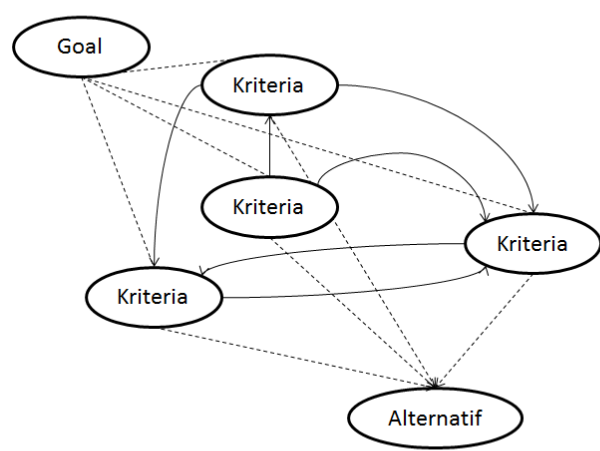

(b)

Gambar 2. (a) Struktur AHP (b) Struktur ANP

Metode ANP mampu memperbaiki kelemahan AHP berupa kemampuan mengakomodasi keterkaitan antar kriteria atau alternatif. Keterkaitan pada metode ANP ada 2 (dua) jenis, yaitu keterkaitan dalam satu set elemen (inner dependence) dan keterkaitan antar elemen yang berbeda (outer dependence). Adanya keterkaitan tersebut menyebabkan metode ANP lebih kompleks dibanding metode AHP (Saaty, 2006). 


\subsection{Konsep Balanced Scorecard (BSC)}

Balanced Scorecard (BSC) pertama kali diperkenalkan oleh Robert S. Kaplan dan David P. Norton (1992) yang digunakan untuk mengukur kinerja perusahaan berdasarkan visi dan strategi yang sudah dijalankan oleh suatu perusahaan. Dengan menggunakan Balanced Scorecard (BSC) suatu perusahaan akan mengetahui, apakah perusahaannya sudah berjalan sesuai strategi yang ada untuk mencapai visi perusahaan, atau belum.

Menurut Himawan, F. A dan Juarsah (2005), Balanced Scorecard merupakan suatu pengukuran kinerja dan sistem manajemen yang memandang perusahaan dari empat perspektif, yaitu perspektif keuangan (financial), pelanggan (customer), proses internal bisnis (internal business process) serta proses pembelajaran dan perkembangan (learning and development) untuk memperbaiki keputusan strategis dalam mencapai tujuan perusahaan serta memberikan pemahaman kepada manajer terhadap performance bisnis.

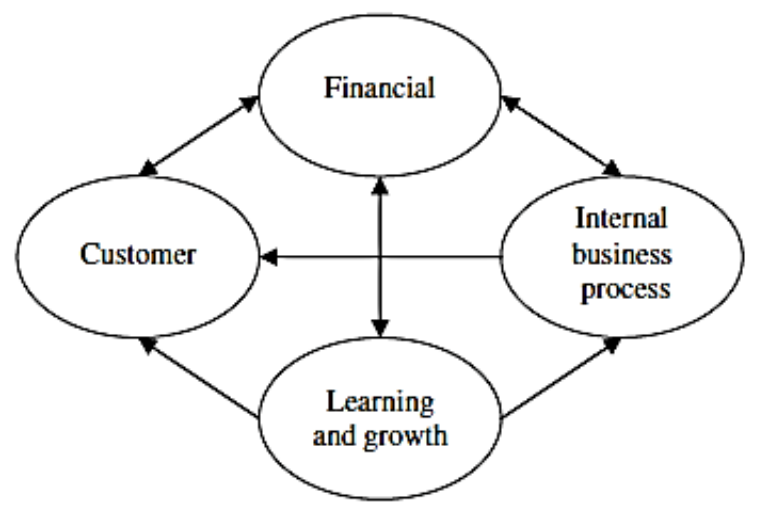

Gambar 3. Hubungan antar perspektif BSC

(Sumber: Yüksel I. \& M. Dağdeviren, 2010)

\subsection{Konsep Balanced Scorecard (BSC)}

Adapun tahapan FANP-BSC adalah sebagai berikut:

a. Penyusunan tahapan dalam Balanced Scorecard (BSC), yaitu:

1) Membentuk tim evaluasi kinerja yang terdiri dari pakar perusahaan dan menentukan visi bisnis.

2) Menentukan strategi yang akan dijalani agar mencapai visi bisnis.

3) Menentukan indikator kinerja berdasarkan perspektif.

b. Penyusunan tahapan BSC menggunakan metode FANP, yaitu

1) Membentuk struktur hierarki model ANP (visi, strategi, perspektif BSC, indikator kinerja).

2) Menentukan bobot lokal dari strategi, perspektif BSC dan indikator kinerja menggunakan matriks perbandingan berpasangan (pairwise comparison matrices) (dengan asumsi bahwa tidak ada keterkaitan antar perspektif BSC). Skala fuzzy yang berhubungan dengan skala kepentingan untuk mengukur bobot relatif digunakan metode Extent Analysis.

3) Menentukan matriks inner dependence dari BSC perspektif yang berhubungan (berdasarkan gambar 3), menggunakan skala fuzzy (Tabel 1). Matriks inner dependence dari BSC digunakan untuk menentukan bobot keterkaitan (interdependent weigths). 
4) Menghitung bobot keterkaitan (interdependent weigths) dengan cara mengalikan matriks inner dependence dengan bobot lokal perspektif BSC yang telah ditentukan pada langkah (c).

5) Menghitung bobot global untuk indikator kinerja. Dengan cara mengalikan bobot lokal indikator kinerja dengan bobot keterkaitan (interdependent weigths).

6) Mengukur indikator kinerja. Variabel linguistik yang dikenalkan oleh Cheng, Yang and Hwang (1999) digunakan pada langkah ini.

Tabel 2. Skala Lingustik

\begin{tabular}{cc}
\hline Nilai lingustik & Bilangan Fuzzy \\
\hline Sangat Tinggi (ST) & 1 \\
Tinggi (T) & 0,75 \\
Sedang (S) & 0,5 \\
Rendah (R) & 0,25 \\
Sangat Rendah (SR) & 0 \\
\hline (Sumber: Cheng et al, 1999)
\end{tabular}

7) Menghitung kinerja bisnis menggunakan bobot global yang dihitung pada langkah (e) dan nilai linguistik yang ditetapkan pada langkah (f).

\section{HASIL DAN PEMBAHASAN}

\subsection{Penerapan FANP-BSC dalam pengukuran kinerja perusahaan}

Suatu Perusahaan XYZ yang bergerak di bidang manufaktur ingin mengukur kinerja perusahaan dengan visi, yaitu "Menjadi pilihan merek pasar", dan memiliki 3 (tiga) strategi, yaitu (Yüksel I., 2010) :

Strategi 1 : Merancang produk berdasarkan kemauan konsumen

Strategi 2 : Mengadopsi teknologi baru yang digunakan dalam phase produksi dan terus meningkatkan kualitas produk

Strategi 3 : Meningkatkan pelayanan kualitas purna jual dengan memperluas jaringan kerja

Tim pakar dari perusahaan telah menentukan indikator kinerja berdasarkan perspektif BSC.

Tabel 3. Perspektif BSC dan Indikatornya

\begin{tabular}{ll}
\hline Perspektif BSC & Indikator \\
\hline Perspektif Keuangan & Aset Keuntungan \\
(Financial) & Keuntungan Penjualan \\
& $\begin{array}{l}\text { Profitabilitas Ekuitas } \\
\text { Arus Keuangan }\end{array}$ \\
Perspektif Pelanggan & Tingkat Kepuasan Pelanggan \\
(Customer) & $\begin{array}{l}\text { Perolehan Pelanggan Baru } \\
\text { Target Pasar Saham }\end{array}$ \\
& Retensi Pelanggan \\
Proses Internal Bisnis & Perkembangan dalam Produk dan Pelayanan \\
(Internal Business & Proses Pengolahan \\
Process) & Jasa Pengantaran Produk \\
& Menciptakan Teknologi Baru \\
\hline
\end{tabular}

Analytic Network Process Pada Balanced Scorecard dengan Pendekatan Fuzzy (Oni Soesanto) | 210 


\begin{tabular}{ll}
\hline Perspektif BSC & Indikator \\
\hline Proses Pembelajaran & Tingkat Kepuasan Karyawan \\
dan Perkembangan & Latihan dan Kemampuan \\
(Learning and & Inovasi \\
Development) & Berbagi Pengetahuan \\
\hline
\end{tabular}

Berdasarkan penyusunan tahapan Balanced Scorecard (BSC) dengan Metode FANP, maka langkah-langkahnya sebagai berikut:

Tahap 1 : Membentuk struktur hierarki model ANP (visi, strategi, perspektif BSC, indikator kinerja)

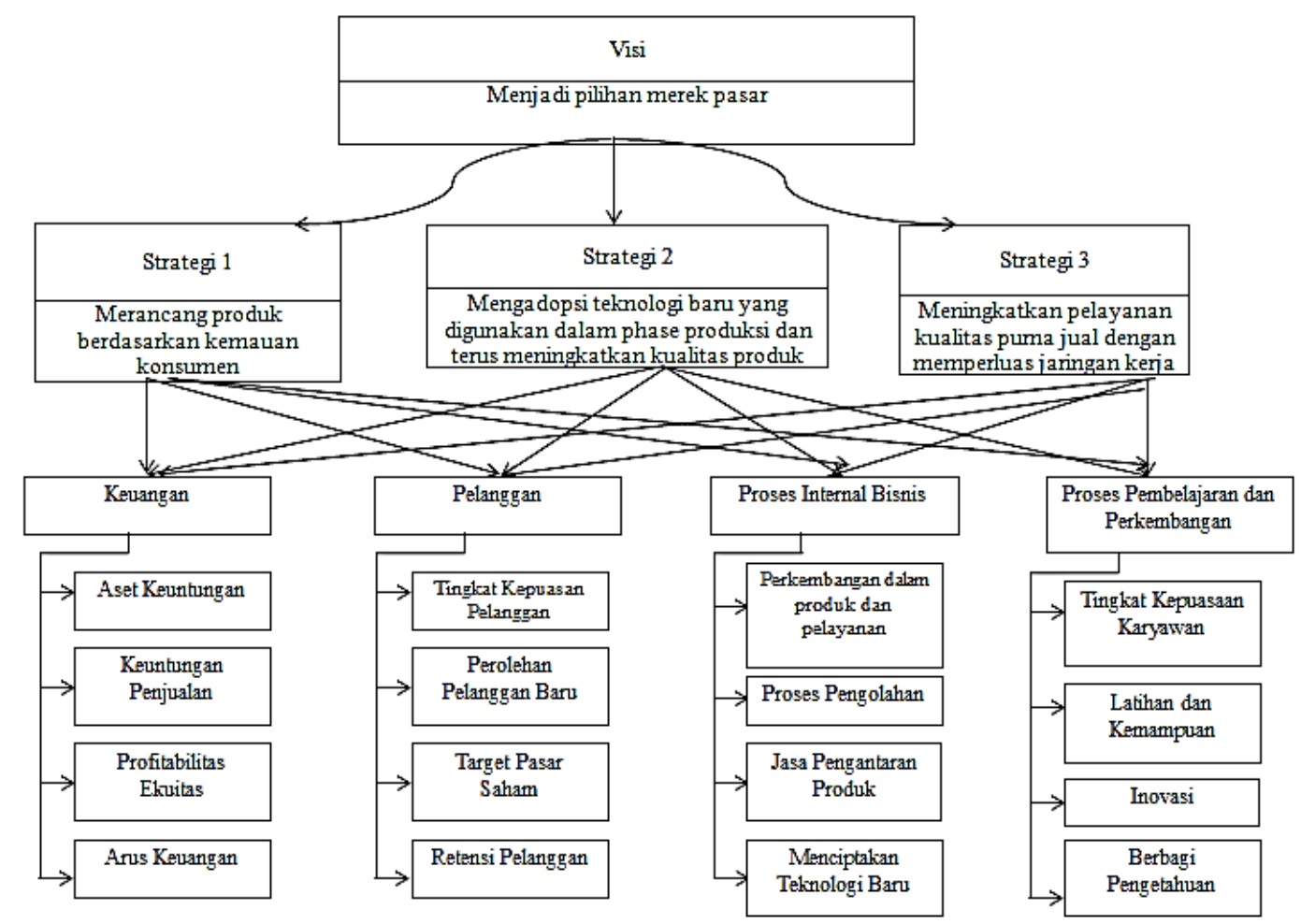

Gambar 4. Struktur Hirarki FANP-BSC

Tahap 3: Membentuk matriks perbandingan berpasangan dari strategi, perspektif BSC dan indikator kinerja, untuk menentukan bobot masing-masing.

Tabel 4. Matriks Perbandingan Kepentingan Berpasangan Antar Strategi

\begin{tabular}{lccc}
\hline Strategi & Strategi 1 & Strategi 2 & Strategi 3 \\
\hline Strategi 1 & Tetap (T) & Sangat Lebih & Sama Pentingnya \\
& & Penting (SG) & (SP) \\
Strategi 2 & Resiprocal SG & Tetap (T) & Sangat Lebih \\
Strategi 3 & Resiprocal SP & Resiprocal SG & Penting (SG) \\
\hline
\end{tabular}


Berdasarkan tabel 4 maka dapat diubah ke dalam skala Triangular Fuzzy Number sebagai berikut:

Tabel 5. Matriks Perbandingan Kepentingan Berpasangan Antar Strategi (Dalam skala triangular fuzzy number)

\begin{tabular}{lcccccc}
\hline Strategi & Strategi 1 & Strategi 2 & Strategi 3 & \multicolumn{3}{c}{ Jumlah Baris } \\
& $(l, m, u)$ & $(l, m, u)$ & $(l, m, u)$ & $l$ & $m$ & $u$ \\
\hline Strategi 1 & $(1,1,1)$ & $(3 / 2,2,5 / 2)$ & $(1 / 2,1,3 / 2)$ & 3,00 & 4,00 & 5,00 \\
Strategi 2 & $(2 / 5,1 / 2,2 / 3)$ & $(1,1,1)$ & $(3 / 2,2,5 / 2)$ & 2,90 & 3,50 & 4,17 \\
Strategi 3 & $(2 / 3,1,2)$ & $(2 / 5,1 / 2,2 / 3)$ & $(1,1,1)$ & 2,07 & 2,50 & 3,67 \\
& Jumlah Kolom $(l, m, u)$ & & $\mathbf{7 , 9 7}$ & $\mathbf{1 0 , 0 0}$ & $\mathbf{1 2 , 8 3}$ \\
\hline
\end{tabular}

Untuk mendapatkan jumlah baris $(l, m, u)$ pada tabel 5 di atas, dilakukan dengan cara : $(1,1,1) \oplus(3 / 2,2,5 / 2) \oplus(1 / 2,1,3 / 2)=(1+3 / 2+1 / 2,1+2+1,1+5 / 2$ $+3 / 2)=(3,00 ; 4,00 ; 5,00)$.

\subsection{Nilai Sintetis Fuzzy}

Setelah nilai jumlah baris dan jumlah kolom $(l, m, u)$ diperoleh dari matriks perbandingan, selanjutnya menggunakan persamaan 9 :

$$
S_{i}=\sum_{j=1}^{m} M_{g i}^{j} \odot\left[\sum_{i=1}^{n} \sum_{j=1}^{m} M_{g i}^{j}\right]^{-1}
$$

Diperoleh nilai sintetis fuzzy untuk masing-masing strategi, sebagai berikut: Nilai sintetis fuzzy masing-masing strategi

Strategi 1

Strategi 2

$$
=(3,00 ; 4,00 ; 5,00) \times\left(\frac{1}{12,83} ; \frac{1}{10,00} ; \frac{1}{7,97}\right)=(0,23 ; 0,40 ; 0,63)
$$

Strategi 3

$$
=(2,90 ; 3,50 ; 4,17) \times\left(\frac{1}{12,83} ; \frac{1}{10,00} ; \frac{1}{7,97}\right)=(0,23 ; 0,35 ; 0,52)
$$

$$
=(2,07 ; 2,50 ; 3,67) \times\left(\frac{1}{12,83} ; \frac{1}{10,00} ; \frac{1}{7,97}\right)=(0,16 ; 0,25 ; 0,46)
$$

Hasil perhitungan untuk nilai sintetis fuzzy di atas dapat dilihat pada tabel 5, sebagai berikut:

Tabel 6. Nilai Sintetis Fuzzy untuk Strategi

\begin{tabular}{cc} 
Strategi & $\begin{array}{c}\text { Nilai Sintetis Fuzzy } \\
(l, m, u)\end{array}$ \\
\hline Strategi 1 & $(0,23 ; 0,40 ; 0,63)$ \\
Strategi 2 & $(0,23 ; 0,35 ; 0,52)$ \\
Strategi 3 & $(0,16 ; 0,25 ; 0,46)$ \\
\hline
\end{tabular}

Nilai sintetis fuzzy pada masing-masing kriteria tersebut akan digunakan untuk mendapatkan degree of possibility (definisi 7). 


\subsection{Derajat Keanggotaan}

Untuk mendapatkan derajat keanggotaan digunakan persamaan 11

$$
V\left(M_{2} \geq M_{1}\right)=\left\{\begin{array}{cc}
1 & , \text { jika } m_{2} \geq m_{1} \\
0 & \text {,jika } l_{1} \geq u_{2} \\
\frac{l_{1}-u_{2}}{\left(m_{2}-u_{2}\right)-\left(m_{1}-l_{1}\right)}, & \text {, }
\end{array}\right.
$$

dengan perhitungan sebagai berikut diperoleh derajat keanggotaan dari perbandingan nilai sintetis fuzzy yaitu:

a. Perbandingan antara Strategi 1 dengan Strategi 2 dan Strategi 3

1) $V\left(S_{1} \geq S_{2}\right)=1$

2) $V\left(S_{1} \geq S_{3}\right)=1$

Dari perhitungan di atas diperoleh nilai-nilai derajat keanggotaan dari perbandingan dua nilai sintetis fuzzy, kemudian diambil yang paling minimum dengan persamaan 12:

Maka diperoleh:

$$
d^{\prime}\left(A_{i}\right)=\min V\left(S_{i} \geq S_{k}\right)
$$

$d^{\prime}($ Strategi 1$)=\min (1 ; 1)=1$

b. Perbandingan antara Strategi 2 dengan Strategi 1 dan Strategi 3

1) $V\left(S_{2} \geq S_{1}\right)=\frac{l_{1}-u_{2}}{\left(m_{2}-u_{2}\right)-\left(m_{1}-l_{1}\right)}=\frac{0,23-0,52}{(0,35-0,52)-(0,40-0,23)}=0,85$

2) $V\left(S_{2} \geq S_{3}\right)=1$

Dari perhitungan di atas diperoleh nilai-nilai derajat keanggotaan dari perbandingan dua nilai sintetis fuzzy, kemudian diambil yang paling minimum dengan persamaan 12 maka diperoleh:

$$
d^{\prime}(\text { Strategi } 2)=\min (1 ; 0,85)=0,85
$$

c. Perbandingan antara Strategi 3 dengan Strategi 1 dan Strategi 2

1) $V\left(S_{3} \geq S_{1}\right)=\frac{l_{1}-u_{3}}{\left(m_{3}-u_{3}\right)-\left(m_{1}-l_{1}\right)}=\frac{0,23-0,46}{(0,25-0,46)-(0,40-0,23)}=0,61$

2) $V\left(S_{3} \geq S_{2}\right)=\frac{l_{2}-u_{3}}{\left(m_{3}-u_{3}\right)-\left(m_{2}-l_{2}\right)}=\frac{0,23-0,46}{(0,25-0,46)-(0,35-0,23)}=0,70$

Dari perhitungan di atas diperoleh nilai-nilai derajat keanggotaan dari perbandingan dua nilai sintetis fuzzy, kemudian diambil yang paling minimum dengan persamaan 12 maka diperoleh:

$d^{\prime}($ Strategi 3$)=\min (0,61 ; 0,70)=0,61$

Maka diperoleh bobot vektor: $W^{\prime}=(1 ; 0,85 ; 0,61)^{T}$

\subsection{Normalisasi Bobot Vektor}

Setelah menentukan bobot vektor untuk masing-masing kriteria, akan dilakukan normalisasi bobot vektor. Sama halnya seperti dalam metode AHP, normalisasi bobot vektor diperoleh dengan membagi masing-masing elemen pada $W^{\prime}$ dengan jumlah keseluruhan elemen pada $W^{\prime}$.

Bobot vektor $\left(W^{\prime}\right)$ untuk strategi, adalah:

$$
W^{\prime}=(1 ; 0,85 ; 0,61)^{T}
$$

Dengan jumlah keseluruhan elemen pada $W^{\prime}$ adalah

$$
1+0,85+0,61=2,46
$$

Sehingga, bobot vektor ternomalisasinya adalah:

$$
W=(1 / 2,46 ; 0,85 / 2,46 ; 0,61 / 2,46)^{T}=(0,41 ; 0,35 ; 0,24)^{T}
$$


Hasil perhitungan normalisasi bobot vektor di atas dapat dilihat pada tabel 7, sebagai berikut:

Tabel 7. Bobot Lokal dan Matriks Perbandingan Kepentingan Berpasangan Antar Strategi

\begin{tabular}{lcccc}
\hline Strategi & Strategi 1 & Strategi 2 & Strategi 3 & Bobot \\
\hline Strategi 1 & $(1,1,1)$ & $(3 / 2,2,5 / 2)$ & $(1 / 2,1,3 / 2)$ & 0,41 \\
Strategi 2 & $(2 / 5,1 / 2,2 / 3)$ & $(1,1,1)$ & $(3 / 2,2,5 / 2)$ & 0,35 \\
Strategi 3 & $(2 / 3,1,2)$ & $(2 / 5,1 / 2,2 / 3)$ & $(1,1,1)$ & 0,24 \\
\hline
\end{tabular}

Setelah tabel ternormalisasi, maka didapatkan nilai vektor bobot normal yang menyatakan nilai kontribusi pada masing-masing strategi pada perusahaan, yaitu strategi 1 sebesar 41\%, strategi 2 sebesar 35\% dan strategi 3 sebesar 25\%. Proses selanjutnya dilakukan untuk setiap perspektif dalam BSC, dan didapatkan tabel bobot berikut:

Tabel 8. Bobot Lokal dan Matriks Perbandingan Kepentingan Berpasangan antar Perspektif BSC pada Masing -Masing Strategi

\begin{tabular}{|c|c|c|c|c|c|}
\hline \multirow{2}{*}{\multicolumn{6}{|c|}{$\begin{array}{l}\text { Perspektif BSC } \\
\text { Strategi } 1\end{array}$}} \\
\hline & & & & & \\
\hline Keuangan $(\mathrm{K})$ & $(1,1,1)$ & $(1 / 2,2 / 3,1)$ & $(1 / 2,2 / 3,1)$ & $(3 / 2,2,5 / 2)$ & 0,20 \\
\hline Pelanggan $(\mathrm{P})$ & $(1,3 / 2,2)$ & $(1,1,1)$ & $(5 / 2,3,7 / 2)$ & $(2 / 7,1 / 3,2 / 5)$ & 0,31 \\
\hline $\begin{array}{l}\text { Proses Internal } \\
\text { Bisnis (PIB) }\end{array}$ & $(1,3 / 2,2)$ & $(2 / 7,1 / 3,2 / 5)$ & $(1,1,1)$ & $(2 / 5,1 / 2,2 / 3)$ & 0,24 \\
\hline $\begin{array}{l}\text { Proses } \\
\text { Pembelaiaran }\end{array}$ & & & & & \\
\hline $\begin{array}{l}\text { Pembelajaran } \\
\text { dan } \\
\text { perkembangan } \\
\text { (PP) }\end{array}$ & $(2 / 5,1 / 2,2 / 3)$ & $(5 / 2,3,7 / 2)$ & $(3 / 2,2,5 / 2)$ & $(1,1,1)$ & 0,25 \\
\hline Strategi 2 & & & & & \\
\hline Keuangan (K) & $(1,1,1)$ & $(2 / 3,1,2)$ & $(1 / 2,2 / 3,1)$ & $(1,1,1)$ & 0,22 \\
\hline Pelanggan (P) & $(1 / 2,1,3 / 2)$ & $(1,1,1)$ & $(2 / 3,1,2)$ & $(1 / 2,1,3 / 2)$ & 0,25 \\
\hline $\begin{array}{l}\text { Proses Internal } \\
\text { Bisnis (PIB) }\end{array}$ & $(1,3 / 2,2)$ & $(1 / 2,1,3 / 2)$ & $(1,1,1)$ & $(1,3 / 2,2)$ & 0,30 \\
\hline Proses & & & & & \\
\hline $\begin{array}{l}\text { Pembelajaran } \\
\text { dan } \\
\text { perkembangan } \\
\text { Strategi } 3\end{array}$ & $(1,1,1)$ & $(2 / 3,1,2)$ & $(1 / 2,2 / 3,1)$ & $(1,1,1)$ & 0,22 \\
\hline Keuangan (K) & $(1,1,1)$ & $(2 / 3,1,2)$ & $(1 / 2,2 / 3,1)$ & $(1,1,1)$ & 0,32 \\
\hline Pelanggan (P) & $(1 / 2,1,3 / 2)$ & $(1,1,1)$ & $(2 / 3,1,2)$ & $(1 / 2,1,3 / 2)$ & 0,32 \\
\hline $\begin{array}{l}\text { Proses Internal } \\
\text { Bisnis (PIB) }\end{array}$ & $(1,3 / 2,2)$ & $(1 / 2,1,3 / 2)$ & $(1,1,1)$ & $(1,3 / 2,2)$ & 0,25 \\
\hline $\begin{array}{l}\text { Proses } \\
\text { Pembelajaran } \\
\text { dan } \\
\text { perkembangan } \\
\text { (PP) }\end{array}$ & $(1,1,1)$ & $(2 / 3,1,2)$ & $(1 / 2,2 / 3,1)$ & $(1,1,1)$ & 0,11 \\
\hline
\end{tabular}

Bobot global dari perspektif BSC ditentukan dengan mengalikan bobot pada tabel 7 dengan bobot strategi: 


$$
W_{B S C}=\left[\begin{array}{c}
K \\
P \\
P I B \\
P P
\end{array}\right]=\left[\begin{array}{lll}
0,20 & 0,22 & 0,32 \\
0,31 & 0,25 & 0,32 \\
0,24 & 0,30 & 0,25 \\
0,25 & 0,22 & 0,11
\end{array}\right] \times\left[\begin{array}{l}
0,41 \\
0,35 \\
0,24
\end{array}\right]=\left[\begin{array}{l}
0,236 \\
0,295 \\
0,264 \\
0,205
\end{array}\right]
$$

Dengan diasumsikan tidak ada hubungan antara perspektif BSC, terlihat bahwa perpektif pelanggan sangat menentukan dengan bobot sebesar 0,291 atau sebesar 29,1\% diikuti dengan perspektif proses Internal Bisnis sebesar 26,3\%, perspektif keuangan sebesar $23,6 \%$ dan perspesktif Proses Pembelajaran dan perkembangansebesar $20,6 \%$.

Pada akhir tahap 2 ini, akan ditentukan bobot dari indikator pada masingmasing perspektif, yaitu sebagai berikut:

Tabel 8. Bobot Lokal dari Indikator Kinerja

\begin{tabular}{|c|c|c|c|c|c|}
\hline Perspektif Keuangan & $\mathrm{U}$ & $\mathrm{KP}$ & $\mathrm{PE}$ & $\mathrm{AK}$ & Bobot \\
\hline Aset Keuntungan (U) & $(1,1,1)$ & $(1,3 / 2,2)$ & $(1,3 / 2,2)$ & $(3 / 2,2,5 / 2)$ & 0,37 \\
\hline $\begin{array}{l}\text { Keuntungan Penjualan } \\
\text { (KP) }\end{array}$ & $(1 / 2,2 / 3,1)$ & $(1,1,1)$ & $(1 / 2,1,3 / 2)$ & $(1,3 / 2,2)$ & 0,25 \\
\hline Profitabilitas Ekuitas (PE) & $(1 / 2,2 / 3,1)$ & $(2 / 3,1,2)$ & $(1,1,1)$ & $(1,3 / 2,2)$ & 0,26 \\
\hline Arus Keuangan (AK) & $(2 / 5,1 / 2,2 / 3)$ & $(1 / 2,2 / 3,1)$ & $(1 / 2,2 / 3,1)$ & $(1,1,1)$ & 0,12 \\
\hline Perspektif Pelanggan & $\mathrm{KP}$ & $\mathrm{P}$ & $\mathrm{TP}$ & $\mathrm{RP}$ & Bobot \\
\hline $\begin{array}{l}\text { Tingkat Kepuasan } \\
\text { Pelanggan (KP) }\end{array}$ & $(1,1,1)$ & $(5 / 2,3,7 / 2)$ & $(2 / 7,1 / 3,2 / 5)$ & $(1,3 / 2,2)$ & 0,31 \\
\hline $\begin{array}{l}\text { Perolehan Pelanggan Baru } \\
\text { (P) }\end{array}$ & $(2 / 7,1 / 3,2 / 5)$ & $(1,1,1)$ & $(3 / 2,2,5 / 2)$ & $(1,3 / 2,2)$ & 0,24 \\
\hline Target Pasar Saham (TP) & $(5 / 2,3,7 / 2)$ & $(2 / 5,1 / 2,2 / 3)$ & $(1,1,1)$ & $(2 / 5,1 / 2,2 / 3)$ & 0,25 \\
\hline Retensi Pelanggan (RP) & $(1 / 2,2 / 3,1)$ & $(1 / 2,2 / 3,1)$ & $(3 / 2,2,5 / 2)$ & $(1,1,1)$ & 0,20 \\
\hline Perspektif PIB & $\mathrm{P}$ & PP & PPr & TB & Bobot \\
\hline $\begin{array}{l}\text { Perkembangan dalam } \\
\text { produk dan pelayanan (P) }\end{array}$ & $(1,1,1)$ & & & $(1,1,1)$ & 0,22 \\
\hline Proses Pengolahan (PP) & $(1 / 2,1,3 / 2)$ & $(1,1,1)$ & $(2 / 3,1,2)$ & $(1 / 2,1,3 / 2)$ & 0,25 \\
\hline $\begin{array}{l}\text { Jasa Pengantaran Produk } \\
\text { (PPr) }\end{array}$ & $(1,3 / 2,2)$ & $(1 / 2,1,3 / 2)$ & $(1,1,1)$ & $(1,3 / 2,2)$ & 0,30 \\
\hline Teknologi Baru (TB) & $(1,1,1)$ & $(2 / 3,1,2)$ & $(1 / 2,2 / 3,1)$ & $(1,1,1)$ & 0,22 \\
\hline $\begin{array}{l}\text { Perspektif Proses } \\
\text { Pembelajaran dan } \\
\text { Perkembangan }\end{array}$ & KP & LK & I & $\mathrm{BP}$ & Bobot \\
\hline $\begin{array}{l}\text { Tingkat Kepuasan } \\
\text { Karyawan (KP) }\end{array}$ & $(1,1,1)$ & $(1,1,1)$ & $(2 / 3,1,2)$ & $(2 / 3,1,2)$ & 0,25 \\
\hline $\begin{array}{l}\text { Latihan dan Kemampuan } \\
\text { (LK) }\end{array}$ & $(1,1,1)$ & $(1,1,1)$ & $(1,1,1)$ & $(2 / 3,1,2)$ & 0,25 \\
\hline Inovasi (I) & $(1 / 2,1,3 / 2)$ & $(1,1,1)$ & $(1,1,1)$ & $(1,1,1)$ & 0,25 \\
\hline Berbagi Pengetahuan (BP) & $(1 / 2,1,3 / 2)$ & $(1 / 2,1,3 / 2)$ & $(1,1,1)$ & $(1,1,1)$ & 0,25 \\
\hline
\end{tabular}

Tahap 3 :Menentukan matriks inner dependence dari BSC perspektif yang berhubungan (berdasarkan gambar 2), menggunakan skala fuzzy (Tabel 1).

Tabel 9. Matriks Inner Dependence yang berhubungan dengan Keuangan

\begin{tabular}{|c|c|c|c|c|}
\hline Keuangan (K) & Pelanggan (P) & $\begin{array}{l}\text { Proses } \\
\text { Internal } \\
\text { Bisnis } \\
\text { (PIB) }\end{array}$ & $\begin{array}{c}\text { Proses } \\
\text { Pembelajaran } \\
\text { dan } \\
\text { perkembangan } \\
\text { (PP) }\end{array}$ & Bobot \\
\hline Pelanggan (P) & $(1,1,1)$ & $(3 / 2,2,5 / 2)$ & $(1,3 / 2,2)$ & 0,56 \\
\hline
\end{tabular}




\begin{tabular}{|c|c|c|c|c|}
\hline Keuangan (K) & Pelanggan $(\mathrm{P})$ & $\begin{array}{l}\text { Proses } \\
\text { Internal } \\
\text { Bisnis } \\
\text { (PIB) }\end{array}$ & $\begin{array}{c}\text { Proses } \\
\text { Pembelajaran } \\
\text { dan } \\
\text { perkembangan } \\
\text { (PP) }\end{array}$ & Bobot \\
\hline Proses Internal Bisnis (PIB) & $(2 / 5,1 / 2,2 / 3)$ & $(1,1,1)$ & $(1 / 2,2 / 3,1)$ & 0,10 \\
\hline $\begin{array}{l}\text { Proses Pembelajaran dan } \\
\text { Perkembangan (PP) }\end{array}$ & $(1 / 2,2 / 3,1)$ & $(1,3 / 2,2)$ & $(1,1,1)$ & 0,34 \\
\hline
\end{tabular}

Tabel 10. Matriks Inner Dependence yang berhubungan dengan Pelanggan

\begin{tabular}{lcccc}
\hline \multicolumn{1}{c}{ Pelanggan (P) } & $\begin{array}{c}\text { Keuangan } \\
(\mathrm{K})\end{array}$ & $\begin{array}{c}\text { Proses } \\
\text { Internal } \\
\text { Bisnis } \\
(\mathrm{PIB})\end{array}$ & $\begin{array}{c}\text { Proses } \\
\text { Pembelajaran dan } \\
\text { perkembangan(PP) }\end{array}$ & Bobot \\
& $(1,1,1)$ & $(1 / 2,1,3 / 2)$ & $(1,3 / 2,2)$ & 0,39 \\
\hline Keuangan (K) & $(2 / 3,1,2)$ & $(1,1,1)$ & $(3 / 2,2,5 / 2)$ & 0,45 \\
Proses Internal Bisnis (PIB) & $(1 / 2,2 / 3,1)$ & $(2 / 5,1 / 2,2 / 3)$ & $(1,1,1)$ & 0,16 \\
Proses Pembelajaran dan & & & & \\
\hline
\end{tabular}

Tabel 11. Matriks Inner Dependence yang berhubungan dengan Proses Intenal Bisnis

\begin{tabular}{lccc}
\hline Proses Internal Bisnis (PIB) & $\begin{array}{c}\text { Keuangan } \\
(\mathrm{K})\end{array}$ & $\begin{array}{c}\text { Proses Pembelajaran dan } \\
\text { perkembangan(PP) }\end{array}$ & Bobot \\
\hline Keuangan (K) & $(1,1,1)$ & $(1,3 / 2,2)$ & 0,68 \\
Proses Pembelajaran dan & $(1 / 2,2 / 3,1)$ & $(1,1,1)$ & 0,32 \\
Perkembangan(PP) & & & \\
\hline
\end{tabular}

Tahap 4 : Menghitung bobot keterkaitan (interdependent weigths) dengan cara mengalikan matriks inner dependence dengan bobot global perspektif BSC yang telah ditentukan pada tahap 2.

$$
W_{B S C}=\left[\begin{array}{c}
K \\
P \\
P I B \\
P P
\end{array}\right]=\left[\begin{array}{cccc}
1,00 & 0,39 & 0,68 & 1,00 \\
0,56 & 1,00 & 0 & 0 \\
0,10 & 0,45 & 1,00 & 0 \\
0,34 & 0,16 & 0,32 & 1,00
\end{array}\right] \times\left[\begin{array}{c}
0,236 \\
0,295 \\
0,264 \\
0,205
\end{array}\right]=\left[\begin{array}{l}
0,368 \\
0,214 \\
0,210 \\
0,208
\end{array}\right]
$$

Terlihat perbedaan yang signifikan pada bobot perspektif BSC ketika keterkaitan antar perspektif diperhatikan. Hasilnya berubah dari 23,6\% menjadi 73,4\%; 29,1\% menjadi 42,3\%; $26,3 \%$ menjadi $41,8 \%$ dan $20,6 \%$ menjadi $41,7 \%$ untuk masing-masing bobot perspektif.

Tahap 5 : Menghitung bobot global untuk indikator kinerja. Dengan cara mengalikan bobot lokal indikator kinerja dengan bobot keterkaitan (interdependent weigths).

Tabel 12. Menghitung Bobot Global dari Indikator Kinerja

\begin{tabular}{lcccc}
\hline Perspektif BSC & $\begin{array}{c}\text { Bobot } \\
\text { Keterkaitan }\end{array}$ & $\begin{array}{c}\text { Indikator } \\
\text { Kinerja }\end{array}$ & Bobot & $\begin{array}{c}\text { Bobot } \\
\text { Global }\end{array}$ \\
\hline Keuangan & 0,368 & $\mathrm{U}$ & 0,37 & 0,136 \\
& & $\mathrm{KP}$ & 0,25 & 0,093 \\
& & $\mathrm{KK}$ & 0,26 & 0,096 \\
Pelanggan & & $\mathrm{AK}$ & 0,12 & 0,045 \\
& 0,214 & $\mathrm{KP}$ & 0,31 & 0,066 \\
& & $\mathrm{P}$ & 0,24 & 0,051 \\
& & $\mathrm{TP}$ & 0,25 & 0,054 \\
Proses Internal Bisnis & & $\mathrm{RP}$ & 0,20 & 0,043 \\
& & $\mathrm{P}$ & 0,22 & 0,046 \\
\hline
\end{tabular}

Analytic Network Process Pada Balanced Scorecard dengan Pendekatan Fuzzy (Oni Soesanto) | 216 


\begin{tabular}{lcccc}
\hline Perspektif BSC & $\begin{array}{c}\text { Bobot } \\
\text { Keterkaitan }\end{array}$ & $\begin{array}{c}\text { Indikator } \\
\text { Kinerja }\end{array}$ & Bobot & $\begin{array}{c}\text { Bobot } \\
\text { Global }\end{array}$ \\
\hline & & PP & 0,25 & 0,053 \\
& & PPr & 0,30 & 0,063 \\
Proses Pembelajaran dan & TB & 0,22 & 0,046 \\
Perkembangan & KP & 0,25 & 0,052 \\
& 0,208 & LK & 0,25 & 0,052 \\
& & I & 0,25 & 0,052 \\
& & BP & 0,25 & 0,052 \\
\hline
\end{tabular}

Tahap 6-7 : Pada tahap ini, kinerja dari suatu perusahaan ditentukan menggunakan nilai bobot global dari indikator kinerja (tabel 12) dan nilai linguistik yang sudah ditetapkan (tabel 13). (diasumsikan bahwa evaluasi linguistik indikator kinerja sudah ditetapkan oleh tim pakar perusahaan)

Tabel 13. Skala Lingustik

\begin{tabular}{ll}
\hline Nilai lingustik & Bilangan Fuzzy \\
\hline Sangat Tinggi (ST) & 1 \\
Tinggi (T) & 0,75 \\
Sedang (S) & 0,5 \\
Rendah (R) & 0,25 \\
Sangat Rendah (SR) & 0 \\
\hline
\end{tabular}

(Sumber: Cheng et al, 1999)

Tabel 14. Pengukuran Indikator menggunakan FANP-BSC

\begin{tabular}{ccccc}
\hline $\begin{array}{c}\text { Indikator } \\
\text { Kinerja }\end{array}$ & $\begin{array}{c}\text { Bobot Global } \\
\text { (BG) }\end{array}$ & $\begin{array}{c}\text { Evaluasi } \\
\text { Linguistik }\end{array}$ & $\begin{array}{c}\text { Nilai Skala } \\
(N S)\end{array}$ & $\begin{array}{c}\text { Indikator } \\
B G \times N S\end{array}$ \\
\hline U & 0,136 & $\mathrm{~S}$ & 0,5 & 0,068 \\
KP & 0,093 & $\mathrm{R}$ & 0,25 & 0,023 \\
PE & 0,096 & $\mathrm{~T}$ & 0,75 & 0,072 \\
AK & 0,045 & $\mathrm{~S}$ & 0,5 & 0,023 \\
KP & 0,066 & $\mathrm{~T}$ & 0,75 & 0,050 \\
P & 0,051 & $\mathrm{~S}$ & 0,5 & 0,026 \\
TP & 0,054 & $\mathrm{~S}$ & 0,5 & 0,027 \\
PP & 0,043 & $\mathrm{~T}$ & 0,75 & 0,032 \\
P & 0,046 & $\mathrm{~S}$ & 0,5 & 0,023 \\
PP & 0,053 & $\mathrm{~T}$ & 0,75 & 0,040 \\
PPr & 0,063 & $\mathrm{ST}$ & 1 & 0,063 \\
TB & 0,046 & $\mathrm{~T}$ & 0,75 & 0,035 \\
KP & 0,052 & $\mathrm{~S}$ & 0,5 & 0,026 \\
LK & 0,052 & $\mathrm{R}$ & 0,25 & 0,013 \\
I & 0,052 & $\mathrm{R}$ & 0,25 & 0,013 \\
BP & 0,052 & $\mathrm{~S}$ & 0,5 & 0,026 \\
\hline \multicolumn{7}{c}{ Total } & & 0,558 \\
\hline
\end{tabular}

Jadi, Perusahaan tersebut telah menjalankan perusahaan berdasarkan indikator kinerja dari perspektif BSC yang sesuai dengan visi dan strategi menggunakan Fuzzy Analytic Network Process (FANP) adalah sebesar 55,8\%. 


\section{KESIMPULAN}

Konsep penerapan metode Fuzzy Analytic Network Process (FANP) pada Balanced Scorecard (BSC), yaitu membentuk tim evaluasi kinerja yang terdiri dari tim pakar perusahaan dan menentukan visi bisnis, menentukan strategi yang akan dijalani agar mencapai visi bisnis, menentukan indikator kinerja berdasarkan perspektif. Kemudian, membentuk struktur hierarki Balanced Scorecard (BSC), melakukan perbandingan pada perspektif BSC dalam masing-masing strategi; perbandingan pada masing-masing indikator kinerja dan perbandingan pada keterkaitan perspektif BSC yang dilakukan oleh tim pakar perusahaan dalam variabel linguistik, variabel linguistik tersebut didefinisikan dalam Triangular Fuzzy Number (TFN) yang akan digunakan dalam pembobotan menggunakan metode extent analysis. Tahap selanjutnya menghitung bobot global indikator kinerja dengan cara mengalikan bobot lokal indikator kinerja dengan bobot ketergantungan (interdependent weights). Tahap terakhir adalah mengukur indikator kinerja dengan cara menjumlahkan hasil perkalian bobot ketergantungan dengan nilai linguistik yang telah ditentukan.

\section{DAFTAR PUSTAKA}

[1] Chang, Da-Yong. 1996. Applications of The Extent Analysis Method on Fuzzy AHP. European Jurnal of Operation Research, Beijing Materials College, Beijing, China. 95: 649-655.

[2] Cheng, D.H., Yang K.L \& Hwang C.L. 1999. Evaluating attack helicopters by AHP based on linguistic variable weight. European Journal of Operational Research. 116: 423-435

[3] Kahraman, C., Ruan, D., \& Dogan, I. 2003. Fuzzy Group Decision-Making for Facility Location Selection. Istanbul Technical University. Belgian Nuclear Research Centre. 157: 135-153.

[4] Kahraman, Cengiz. 2008. Fuzzy Multi-Criteria Decision Making. Istanbul Tecnichal University, Turki.

[5] Kaplan, R. S., \& Norton, D. P. 1996. Using The Balanced Scorecard as a Strategic Management System. Harvard Business Review. 74: 75-85.

[6] Lee, A. H. I., Chen, W. C., \& Chang, C. J. 2008. A Fuzzy AHP and BSC Approach for Evaluating Performance of IT Department in The Manufacturing Industry in Taiwan. Elsevier. 34: 96-107.

[7] Rosid, Ahmad. 2010. Pengukuran Kinerja Perusahaan dengan metode Balanced Scorecard dan Analytic Netrowk Process (ANP) pada PT. Setiaji Mandiri. Skripsi Program Studi Teknik Industri, Universitas Islam Negeri Sunan Kalijaga, Yogyakarta.

[8] Saaty, T.L. 1999. Fundamentals of The Analytic Network Process. University of Pittsburgh Mervis Hall, USA.

[9] Tominanto. 2012. Sistem Pendukung Keputusan dengan Metode Analytical Hierarchy Process (AHP). ISSN: 2086-2628.

[10] Yüksel I. \& M. Dağdeviren. 2010. Using the fuzzy analytic network process (ANP) for balanced scorecard (BSC): a case study for a manufacturing firm. Expert Systems with Applications 37 (2) (2010) 1270-1278.

[11] Zadeh, L.A. 1965. Fuzzy Sets, Information And Control, 8: 338-353.

Analytic Network Process Pada Balanced Scorecard dengan Pendekatan Fuzzy (Oni Soesanto) | 218 
[12] Zarghami, Mahdi and Ferene Szidarovszky. 2011. Multicriteria Analysis Applications to Water and Environment Management. Springer. London.

[13] Zimmerman, H, J. 1991. Fuzzy Set Theory and Its Applications. Kluwer Publishing. Co. Amsterdam. 